\title{
Changes in Enzymatic Activities and Microbial Communities in Soil under Long-Term Maize Monoculture and Crop Rotation
}

\author{
Anna Galązka ${ }^{1 *}$, Karolina Gawryjołek ${ }^{1}$, Andrzej Perzyński ${ }^{1}$, \\ Rafal Gałązka ${ }^{3}$, Jerzy Księżak ${ }^{2}$ \\ ${ }^{1}$ Department of Agriculture Microbiology, \\ ${ }^{2}$ Department of Forage Crop Production \\ ${ }^{3}$ Department of Soil Science Erosion and Land Protection \\ Institute of Soil Science and Plant Cultivation - State Research Institute, \\ Czartoryskich 8, 24-100 Puławy, Poland
}

Received: 15 July 2016

Accepted: 18 August 2016

\begin{abstract}
The aim of this work was to examine the effects of long-term maize monoculture and crop rotation on biological activities of soil, especially soil enzymatic activities and microbial communities. We investigated the reaction of maize cultivated in perennial monoculture with direct sowing and compared it to full tillage monoculture and crop rotation full tillage cultivation in the following phases: six leaves, 12 leaves, flowering phase, before harvest, and after harvest. The results of the experiment conducted from 2004 to 2012 in the Experimental Station in Grabów (Mazowieckie Voivodship) on podzolic soil (very good rye soil), were the basis for this elaboration. Three objects were included in this research: maize cropped continuously (monoculture) with zero tillage, maize monoculture cropped continuously with full tillage, and crop rotation (spring barley, winter wheat, maize) with full tillage. The evaluation of the biological activity of the soil was based on the determination of the number of basic groups of soil microorganisms and enzyme activities. The maize was sown with the use of a seed drill. The statistically significant increase in soil enzymatic activity and total number of bacteria and actinomycetes in soil were observed where direct sowing in monoculture was implemented.
\end{abstract}

Keywords: monoculture, crop rotation, maize, microbial communities, enzymatic activities

\section{Introduction}

The main processes in soil, including organic matter decomposition and nutrient cycling in the ecosystem,

*e-mail: agalazka@iung.pulawy.pl depend on soil microbial activity [1-3]. Chemical, physical, and biological properties are involved in soil functioning and all have been extensively used to measure soil quality. Physical and chemical properties of soil usually change slowly. In contrast, microbial and biochemical properties respond rapidly to even small changes in soil status, and thus are considered early indicators of soil 
alteration induced by agricultural management [4-5]. The indicators of soil quality include soil chemical properties (i.e., $\mathrm{pH}$, cation exchange capacity, nutrient reserves, ionic diffusion), physical properties (i.e., soil texture and structure, available water capacity, pore size distribution, water movement, erosion), biological properties (i.e., soil organic carbon, microbial biomass, soil biodiversity, mineralization, respiration), and the interaction between them [6-7].

Soil microorganisms (bacteria, fungi, actinomycetes) represent the largest fraction of organisms, both in terms of biomass and number [8]. These microorganisms play a key role in decomposing organic matter entering the soil. Microbiological processes in soil have been measured using several parameters, such as microbial biomass, respiration, and enzymatic activities. Enzyme activity is essential in both mineralisation and transformation of organic $\mathrm{C}$ and plant nutrients [6]. The number of biological and biochemical properties can be used as early and sensitive indicators of soil organic matter transformations and dynamics, nutrient cycling, and stress and recovery conditions in soil. Many authors are of the opinion that the measurement of soil enzymes and soil microbial communities can be used as indicative of the biological activities and natural biochemical processes in soil [6-10]. The numbers of microorganisms are also an indicator of changes taking place in the soil environment and plant cultivation [8]. Soil microorganisms participate in the processes that are crucial for long-term sustainability of agricultural systems [11-12].

Tillage practices, methods of seedbed preparation, and residue management have an important impact on soil degradation and biological activities [13-14]. In general, soil biological properties of the surface layer are more favorable under the no-tillage method with crop residue mulch than under the plough-tillage method without residue mulch [15]. In crop rotation, plant production depends primarily on nutrient cycling in soils that are controlled by soil microorganisms and soil enzymes [16]. The long-term monoculture may change soil parameters - especially soil microorganisms and enzymes. However, in the opinion of other authors that parameter does not fully reflect the true microbiological activity of soil [1316]. A large number of soil microorganisms are inactive or incapable of growth on artificial substrates [6]. The numbers and activity of these microorganisms are determined by many biotic and abiotic factors that may stimulate or inhibit microbial activity [6].

Maize (Zea mays L.) is one of the most important cultivated plants widely used in agriculture and industry. Numerous applications of this plant have been confirmed, mostly in agriculture and industry, where maize production may be an inexhaustible source of renewable resources $[14,17-18]$. It is known that cultivation of maize requires a lot of work and energy and commitment of many means of production. Economic and environmental considerations tend to the use of simplified tillage cultivation of maize, and even direct sowing. The biggest economic savings of maize cultivation is obtained by using direct seeding
[15]. Maize is one of the plants grown increasingly in notillage while leaving crop residues on the surface of the field. Monoculture maize cultivation is being practiced in many countries. However, the effects of such a system on soil quality is not very much recognized for longterm cultivation. Research on the effects of long-term cultivation of maize in monoculture and direct sowing on changes of soil quality, vegetation, and maize yield are conducted in IUNG for many years [14-15, 18-19].

The aim of this study was to investigate dynamics of the number of microorganisms and enzymatic activities in the soil in long-term monoculture of maize. Therefore, the objective of this experiment was to evaluate effects of a wide range of tillage and crop residue management treatments on changes in biological properties of soil with continuous cultivation of monoculture maize. More specifically, the objective was to assess the long-term trends in tillage-induced changes in soil biological quality, and establish possible cause-effect relationships between management practices and soil biological activities due to monoculture maize cultivation.

\section{Materials and Methods}

\section{Field Experiment}

We conducted our study in the long-term stationary field experiment established in 2004 involving maize cropped continuously and rotated with other crops. We conducted the field experiment 2004-12 at the Agricultural Experimental Station (AES) of the Institute of Soil Science and Plant Cultivation in Grabow, in Poland's Mazowieckie Voivodship $\left(51^{\circ} 23^{\prime} \mathrm{N} ; 2^{\circ} 38^{\prime} \mathrm{E}\right)$. The experimental scheme involved three treatments: maize monoculture with direct seeding (zero tillage), maize monoculture with full ploughing tillage with cultivating measures, and cultivation in crop rotation (spring barley, winter wheat, maize) with full ploughing tillage. Research at AES in Grabow was conducted on a grey brown podsolic soil formed from light loam classified as very good rye complex. The ploughing layer of soil was characterized by low magnesium content, medium potassium content, and high phosphorus content. The experiment was established with the method of long strips with a mirror image of treatments.

In the conventional tillage treatment, straw residues were left after the cob harvest and then shredded and turned under. By contrast, in the non-tillage treatment the straw was shredded but left on the soil surface. Under the crop rotation management all crop species involved were grown each year and full FYM dose was applied to maize. On dairy farms it is frequently the only species to which FYM can be applied. Maize cv. Delitop was seeded using a precision maize planter. Cv. Antek of spring barley and cv. Turnia of wheat were seeded. Nitrogen was applied to maize at a rate of $140 \mathrm{~kg} \mathrm{~N} \mathrm{ha}^{-1}(70+70)$, phosphorus and potassium rates $\left(\mathrm{kg} \mathrm{ha}^{-1}\right)$ were $80 \mathrm{P}_{2} \mathrm{O}_{5}$ and $125 \mathrm{~K}_{2} \mathrm{O}$. Annual fertilizer rates supplied to barley were $60 \mathrm{~N}$, 
$35 \mathrm{P}_{2} \mathrm{O}_{5}$, and $50 \mathrm{~kg} \mathrm{ha}^{-1} \mathrm{~K}_{2} \mathrm{O}$, and to wheat $120 \mathrm{~N}, 40 \mathrm{P}_{2} \mathrm{O}_{5}$, and $70 \mathrm{~kg} \mathrm{ha}^{-1} \mathrm{~K}_{2} \mathrm{O}$. In order to measure the effects of maize tillage prior to the onset and after termination of the trial we assessed $\mathrm{pH}$ in $\mathrm{KCl}$ and soil contents (mg per $100 \mathrm{~g}$ of soil) of $\mathrm{P}_{2} \mathrm{O}_{5}$ (CFA method), $\mathrm{K}_{2} \mathrm{O}$ (FES method), $\mathrm{MgO}$ (AAS method), percentage of total nitrogen (CFA method), and humus content (Tiurin's method). The results of this work are already published [13, 19]. The yields of maize (plant height, weight of 1000 grains, parameters of maize cobs, plant density of harvest, grain yields of cereals) also were published [19].

\section{Soil Samples}

Soil samples were collected according to Polish Standard PN-ISO 1038-6 [20]. Soil samples were taken for microbiological analyses at five dates: before sowing, at the six-leaf stage, 12-leaf stage, flowering, and after harvest. The soil samples in three replicates were taken from the $0-20 \mathrm{~cm}$ layer and sieved through a $2 \mathrm{~mm}$ sieve and stored in a refrigerator $\left(4^{\circ} \mathrm{C}\right)$ until analysis.

\section{Bacterial Communities Analysis}

The soil samples were examined for different groups of microorganisms. Microbiological counts were expressed as a number of colony-forming units (CFUs) per g of dry soil. The number of microorganisms was determined by the dilution method on agarized selective medium. The total number of microorganisms was determined by the dilution method on agarized soil extract. The total number of fungi was determined on Martin's medium [21]. The number of oligotrophic and copiotrophic bacteria also were determined [22]. The $\mathrm{pH}\left(\right.$ in $\left.\mathrm{H}_{2} \mathrm{O}\right)$ and water content (gravimetrically, after drying at $105^{\circ} \mathrm{C}$ ) also were determined.

\section{Enzymatic Activities Analysis}

The enzymatic activities were determined spectrophotometrically: soil dehydrogenase activity using TTC method [23], phosphatase activity by p-NPP method [24]. Thesix gramofsoilwereplacedinatesttube, mixedwith $0.2 \mathrm{~g} \mathrm{CaCO}_{3}, 1 \mathrm{~mL}$ TTC (2,3,5-triphenyltetrazolium chloride as an electron acceptor), and $2.5 \mathrm{~mL}$ distilled water. The tubes were corked and incubated for $24 \mathrm{~h}$ at $37^{\circ} \mathrm{C}$. Triphenylformazan (TPF) was extracted with ethanol and the intensity of the reddish colour was measured on an Evolution 60 Thermo Scientific spectrophotometer at a wavelength of $485 \mathrm{~nm}$ with ethanol as a blank. All dehydrogenase activity determinations were done in triplicate and the results were expressed as an arithmetic mean.

Phosphatase activity was determined using p-nitrophenylphosphate as a substrate. The released p-nitrophenol was extracted, coloured, and measured spectrphotometrically. After the addition of buffered p-nitrophenyl phosphate solution, soil samples are incubated for $1 \mathrm{~h}$ at $37^{\circ} \mathrm{C}$. The p-nitrophenol released by phosphomonoesterase activity is extracted and coloured with sodium hydroxice and determined photometrically at $400 \mathrm{~nm}$.

\section{Statistical Analysis}

The results were elaborated upon statistically. Oneand two-way analysis of variance (AVOVA) were used in a proper model for the experimental design, as well as an analysis of the multi-way experiment in the combined error model, finding $\mathrm{F}$ calculated based on the reproduced error increased by an interaction of the factor with years. Tukey's test was used to evaluate the significance of differences in the means at a significance level of $\mathrm{p} \leq 0.05$.

\section{Results and Discussion}

Reduction in conventional elements of agrotechnology often requires the use of treatments reducing their negative habitat and production effects. This role may be fulfilled by incorporating microbiological preparations into the soil $[6,25-26]$. The post-harvest residues in direct sowing beneficially affect soil properties. Their effect depends, among other things, on the method of placing them in the soil and the dynamics of their decomposition, which is determined by a tillage system $[5,27]$. More frequently used no-plough tillage and direct sowing result in leaving a large amount of post-harvest residues on the soil surface, which has an effect on their decomposition and on nutrient management. This type of tillage has a lot of organizational and economic advantages and may benefit the biological properties of the soil $[6,13]$. However, this can often lead to an increase in its density and - compared with conventional tillage - is the cause of an impediment in its emergence, reduction in development of the root system, and plant yield.

The soil microflora is responsible for the decomposition and conversion of organic substances, aggregation stability, and the carbon, nitrogen, sulfur, and phosphorus cycles. A review of literature shows that the microbiological and biochemical indicators mentioned above have been used many times in studies on biological activities in soil [56,27].

During the nine-year experimental period, total bacteria and fungi numbers were determined five times annually (Fig 1). The highest number of bacteria was observed in soil under maize in two stages: flowering and after harvest (Fig. 1a). The highest number of fungi was observed after the harvest of plants. Statistically significant differences in the average total number of bacteria and fungi were not observed in 2004-12 except for 2009, when there was a statistically significant increase in the total number of fungi (Fig. 1b). This fact was mainly due to weather conditions. Considering three treatments: direct seeding (zero tillage), full ploughing tillage, and crop rotation, the highest total numbers of bacteria and fungi were observed in variants of maize cultivated in monoculture (direct seeding) (Fig. 1c). There were no statistically significant differences in the 
a)

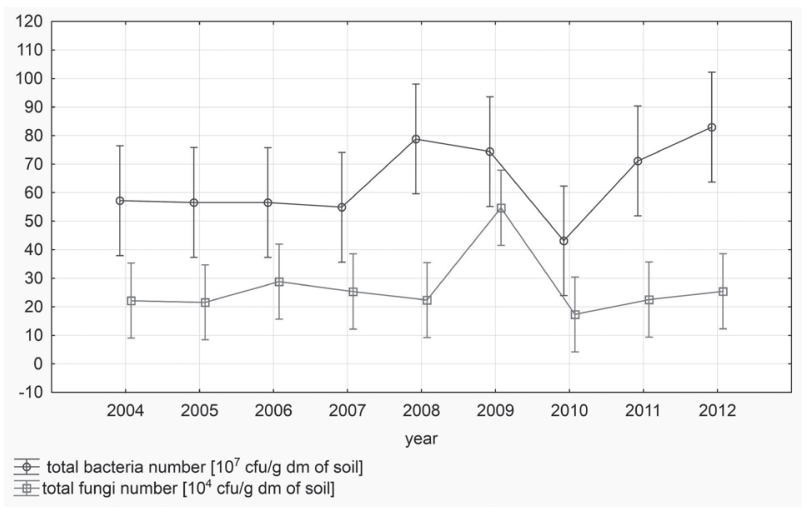

b)

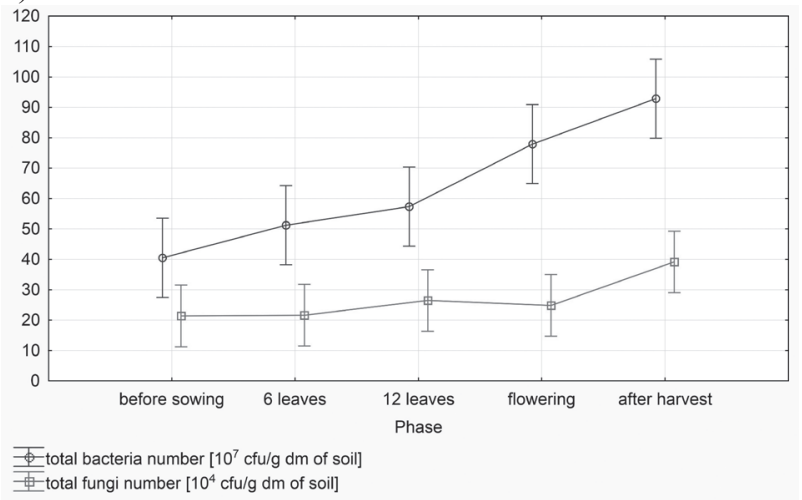

c)

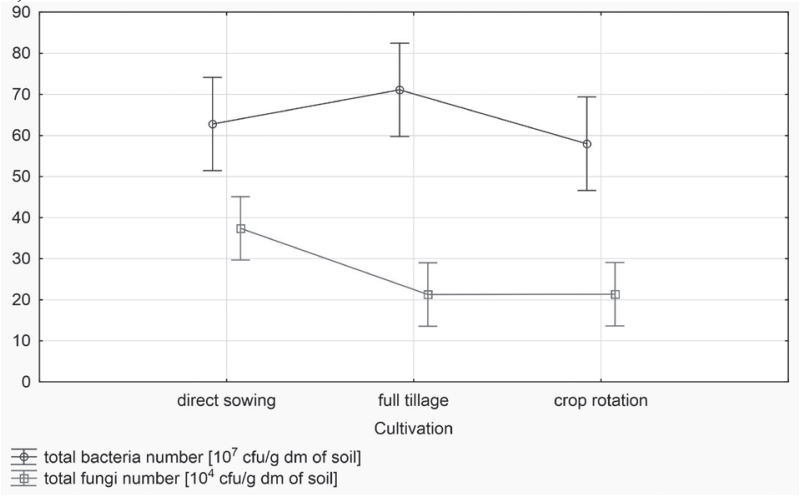

Fig. 1.The total number of bacteria and fungi in soil under maize a) in different years, b) in different phase of plants and c) in different cultivation systems.

Note: Effective hypothesis decomposition Vertical bars denote 0,95 confidence intervals; a) year; LS Means Wilks lambda $=76912, \mathrm{~F}(16,250)=2,1915, \mathrm{p}=00593, \mathrm{~b})$ Phase; LS Means Wilks lambda $=73501, \mathrm{~F}(8,258)=5,3670, \mathrm{p}=00000$, c) Cultivation; LS Means Wilks lambda $=89579, \mathrm{~F}(4,262)=$ $3,7051, \mathrm{p}=00593$.

total number of bacteria and total number of fungi in the variants of maize grown in crop rotation and full ploughing tillage. Also, the total number number of oligotrophic and copiotrophic bacteria were observed in soil under maize cultivated in the no-tillage system and maize cultivated in full ploughing tillage (Table 1). The copiotrophic bacteria is a specific group of soil microorganisms intensively proliferating during the flow of organic matter into the soil, mainly in the form of plant and animal remains. Therefore, their requirements are connected with a high concentration of organic components in substrates and their optimal dose is about $1 \mathrm{mg}$ of soluble $\mathrm{C} / \mathrm{L}$. The highest number of copiotrophic bacteria was observed in soil under maize in monoculture (direct sowing) in flowering phase and also in soil after harvest in the same treatment (Table 1). As well as copiotrophic bacteria, the highest number of oligotrophic bacteria was observed in soil under maize in monoculture (direct sowing) in flowering phase harvest in the same treatment. The oligotrophic bacteria represent microorganisms that grow in environments with a low availability of organic compounds [22]. Optimal concentration of nutritive components for oligothrophs oscillates from 1 to $15 \mathrm{mg}$ of solved C/L. The notion of oligotrophy refers to bacteria that grow in a poor substrate with low concentration of nutritive components only at the beginning of breeding. On the other hand, in successive sowing these bacteria also grow well in a substrate rich in nutritive components [13].

The dynamics of soil microorganism development expressed by changes in the number of the particular groups of microorganisms settled in this environment, i.e., the total number of bacteria, fungi, actinomycetes, and many others is a measurable indicator of the biological life of soil [25]. Soil microorganisms occur in significant amounts and in great variety. Soil favours their development because they fulfil all necessary conditions for their correct growth and development. The development and activity of soil microflora are closely related to plant life. The absence of microorganisms in soil would cause the extinction of higher plants because of mineral famine, and the absence of higher plants would lead to the disappearance of microorganisms. The occurrence of microorganisms depends also on the presence of allopathic compounds secreted by plant roots as well as by mutual interactions between different groups of microorganisms in the soil [4]. Maize is characterized by a large number of root exudates, which is a very good medium for growth and development of many different groups of bacteria and fungi.

The differences in microbial communities in soils under different management were subtle rather than dramatic, and many of the measured parameters showed no consistent significant differences $[25,27]$. The results of our studies also confirm this hypothesis.

The microbiological activity of soils is closely related with organic matter susceptibility to oxidation, as the processes of mineralization and humification in principle consist of oxidation reactions proceeding with the participation of enzymes [4, 28]. Soil enzymes are strongly associated with microorganisms and they play an important role in catalyzing reactions indispensable in life processes of soil microorganisms, decomposition of organic residues, circulation of nutrients, and forming organic matter and soil structure [29-31]. Thus it is possible 
Table 1. Total number of bacteria and fungi (CFU in $1 \mathrm{~g}$ of $\mathrm{dm}$ of soil) under long-term maize monoculture and crop rotation.

\begin{tabular}{|c|c|c|c|c|c|c|}
\hline & \multicolumn{3}{|c|}{$\begin{array}{l}\text { Total oligotrophic bacteria } \\
\left(10^{6} \mathrm{CFU} \text { in } 1 \mathrm{~g} \text { of } \mathrm{dm} \text { of soil }\right) \text {, mean }\end{array}$} & \multicolumn{3}{|c|}{$\begin{array}{l}\text { Total copiotrophic bacteria } \\
\left(10^{6} \mathrm{CFU} \text { in } 1 \mathrm{~g} \text { of } \mathrm{dm} \text { of soil }\right), \text { mean }\end{array}$} \\
\hline & $2004-06$ & 2007-09 & $2010-12$ & 2004-06 & $2007-09$ & $2010-12$ \\
\hline \multicolumn{7}{|c|}{ Monoculture, no tillage (direct sowing) } \\
\hline Before sowing & $23.34^{\mathrm{b}}$ & $62.60^{\mathrm{b}}$ & $60.02^{b}$ & $28.24^{\mathrm{b}}$ & $28.60^{\mathrm{b}}$ & $54.45^{\mathrm{b}}$ \\
\hline Six-leaf stage & $97.07^{b}$ & $136.54^{\mathrm{a}}$ & $86.96^{\mathrm{b}}$ & $33.67^{b}$ & $31.20^{\mathrm{b}}$ & $68.79^{\mathrm{b}}$ \\
\hline 12-leaf stage & $117.66^{\mathrm{a}}$ & $134.90^{\mathrm{a}}$ & $107.35^{\mathrm{a}}$ & $40.12^{\mathrm{b}}$ & $33.46^{\mathrm{b}}$ & $54.08^{\mathrm{b}}$ \\
\hline Flowering & $176.36^{\mathrm{a}}$ & $127.88^{\mathrm{a}}$ & $127.61^{\mathrm{a}}$ & $72.49^{\mathrm{a}}$ & $62.40^{\mathrm{a}}$ & $98.43^{\mathrm{a}}$ \\
\hline After harvest & $179.64^{\mathrm{a}}$ & $157.09^{\mathrm{a}}$ & $257.48^{\mathrm{a}}$ & $81.33^{\mathrm{a}}$ & $82.47^{\mathrm{a}}$ & $124.20^{\mathrm{a}}$ \\
\hline \multicolumn{7}{|c|}{ Monoculture, full tillage } \\
\hline Before sowing & $48.02^{b}$ & $63.67^{\mathrm{b}}$ & $179.13^{\mathrm{a}}$ & $29.66^{b}$ & $47.98^{b}$ & $67.41^{\mathrm{a}}$ \\
\hline Six-leaf stage & $65.92^{\mathrm{b}}$ & $86.77^{\mathrm{a}}$ & $66.15^{b}$ & $20.82^{b}$ & $37.44^{b}$ & $33.84^{\mathrm{b}}$ \\
\hline 12-leaf stage & $56.32^{\mathrm{b}}$ & $104.49^{\mathrm{a}}$ & $154.07^{\mathrm{a}}$ & $45.47^{\mathrm{b}}$ & $37.26^{\mathrm{b}}$ & $67.67^{\mathrm{a}}$ \\
\hline Flowering & $72.06^{\mathrm{a}}$ & $108.68^{\mathrm{a}}$ & $140.65^{\mathrm{a}}$ & $78.37^{\mathrm{a}}$ & $86.83^{\mathrm{a}}$ & $94.31^{\mathrm{a}}$ \\
\hline After harvest & $107.05^{\mathrm{a}}$ & $164.97^{\mathrm{a}}$ & $242.69^{\mathrm{a}}$ & $67.67^{\mathrm{a}}$ & $59.34^{\mathrm{b}}$ & $55.81^{\mathrm{b}}$ \\
\hline \multicolumn{7}{|c|}{ Crop rotation*, full tillage } \\
\hline Before sowing & $26.15^{\mathrm{b}}$ & $36.88^{b}$ & $101.89^{\mathrm{a}}$ & $17.43^{b}$ & $30.39^{b}$ & $50.33^{\mathrm{a}}$ \\
\hline Six-leaf stage & $41.23^{\mathrm{b}}$ & $53.40^{\mathrm{b}}$ & $65.41^{\mathrm{b}}$ & $27.13^{b}$ & $31.46^{\mathrm{b}}$ & $43.04^{b}$ \\
\hline 12-leaf stage & $55.71^{\mathrm{b}}$ & $82.00^{\mathrm{b}}$ & $156.09^{\mathrm{a}}$ & $40.18^{b}$ & $51.16^{\mathrm{b}}$ & $134.36^{\mathrm{a}}$ \\
\hline Flowering & $27.02^{\mathrm{b}}$ & $48.27^{b}$ & $58.93^{\mathrm{b}}$ & $29.98^{b}$ & $70.18^{a}$ & $60.32^{\mathrm{b}}$ \\
\hline After harvest & $45.27^{\mathrm{b}}$ & $148.95^{\mathrm{a}}$ & $121.53^{\mathrm{a}}$ & $36.00^{\mathrm{b}}$ & $47.73^{\mathrm{a}}$ & $78.73^{\mathrm{a}}$ \\
\hline
\end{tabular}

Values in columns followed by the same letter are not significantly different $(\mathrm{p} \leq 0.05)$

*Crop rotation (spring barley, winter wheat, maize) full ploughing tillage

Notes: CFU is colony-forming units

to say that without proper soil enzyme systems, soil life processes will be disturbed. Dehydrogenase (DHA) (Fig. 2) and phosphatase activities (Fig. 3) are good indicators of changes of soil parameters and widely used microbial parameters of soil biology.

Dehydrogenases, as respiratory chain enzymes, play a major role in energy production by organisms. They oxidize organic compounds by transferring two hydrogen atoms. Dehydrogenases are closely related to the microbiological activity of soils as they occur not only within living cells, where they catalyze the oxidoreductive processes [9]. They reflect physiologically active microorganisms and thus provide correlative information on biological activities and microbial populations in soils [4]. The statistically significant differences in dehydrogenase activity were observed in 2008 after four years of research (Fig. 2a). Since then, we observed a statistically significant increase of dehydrogenase activity in soil. As for the total number of bacteria, the highest dehydrogenase activity was observed in two phases: flowering and after harvest (Fig 2b). The dehydrogenase activity was statistically significantly higher in soil under maize cultivated in the no-tillage system (direct sowing) (Fig 2c), which is in correlation with the increased number of the most examined groups of microorganisms.

Seasonal variations in both microbial community and soil enzymatic activities reflect the combined effects of temperature, moisture, substrate availability, and other environmental factors. Dehydrogenases belong to the enzymes displaying strong fluctuations in their activities caused by season, as they are in close relation to microbial activity dynamics. The highest DHA levels in summer and autumn and the lowest in winter were observed by Yuan and Yue [11]. Similar to our observations, related high DHA activity from spring to autumn was noted by Włodarczyk [10]. The author performed analysis on an orthic luvisol sample showing that DHA demonstrated a seasonal pattern and reached the highest values in autumn and the lowest in winter [10]. The maximum DHA in autumn and its reduction in winter was also observed by Tripathi et al. [8]. The level of enzymatic activity of soil depended greatly on the season $[9,27]$. The studies of other authors indicate that enzymes are comparatively active in spring, while in summer they follow a decrease of their activity [8]. This phenomenon was probably connected with the quantitative composition of root secretions of maize. Plants, through their own root secretions as well as by the substances developing as a result of post-harvest 
a)

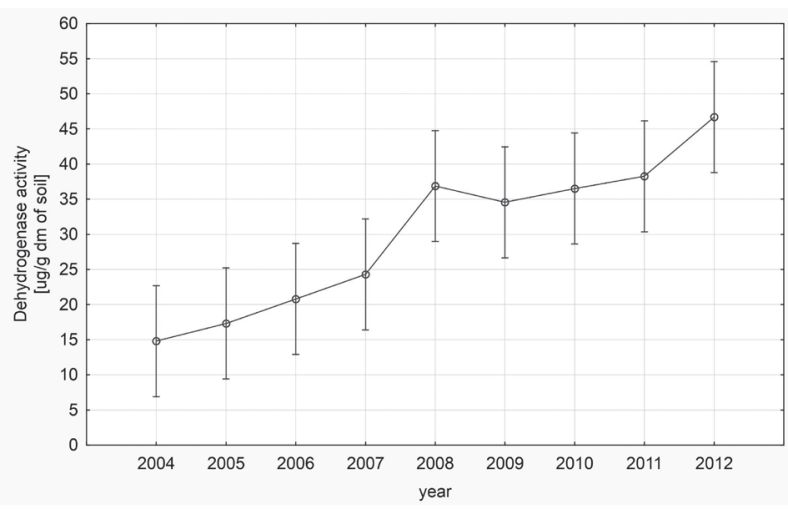

b)

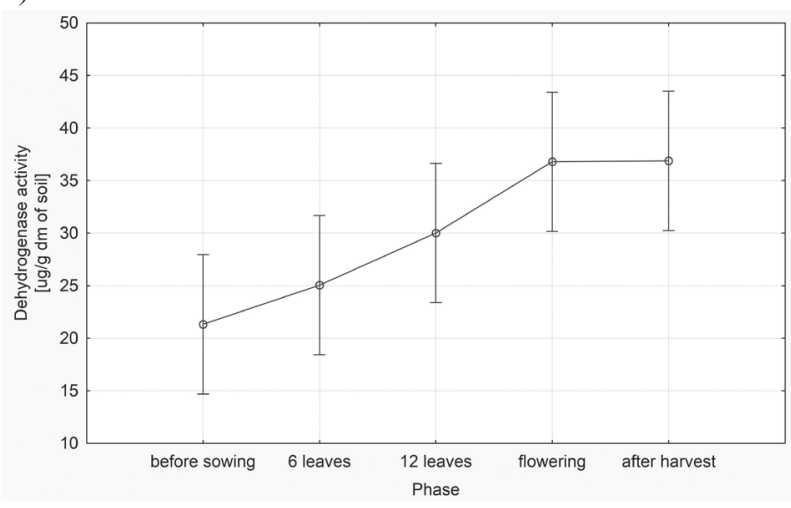

c)

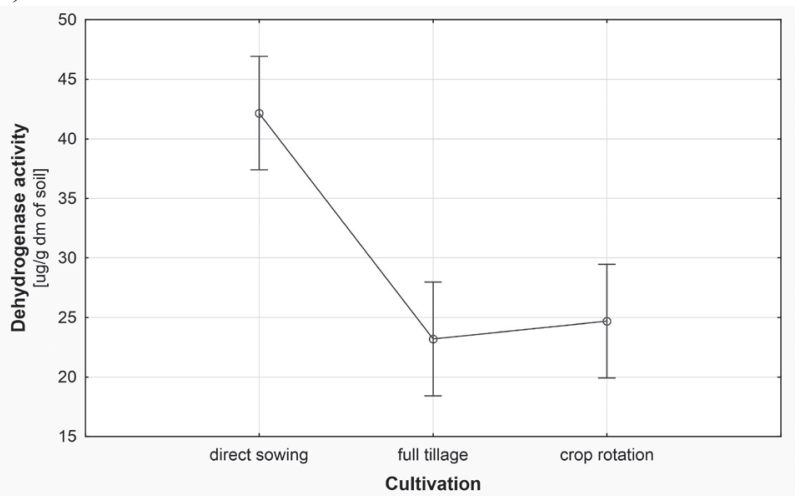

Fig. 2. Dehydrogenase activities in soil under maize a) in different years, $b$ ) in different phase of plants, and c)in different cultivation systems.

Note: Effective hypothesis decomposition Vertical bars denote 0,95 confidence intervals, a)YEAR; LS Means Current effect: $\mathrm{F}(8,126)=7,5855, \mathrm{p}=00000, \mathrm{~b})$ Phase; LS Means Current effect: $\mathrm{F}(4,130)=4,3007, \mathrm{p}=, 00267$, c) Cultivation; LS Means Current effect: $F(2,132)=19,080, p=00000$.

remains, act in different ways on soil microorganisms. Maize produces significant quantities of root secretions that may include aminoacids, hydrocarbons, vitamins, organic acids, and enzymes. These substances inhibit or stimulate the growth and development of microorganisms $[26,32]$.
Another factor that can influence the biochemical activity of soil is the method of plant cultivation. Plant cultivation in monoculture and intensive cultivation have a negative impact on the enzymatic activity of soil [25-26]. Plant cultivation in monoculture continued for many years is accompanied by a one-sided exhaustion of nutritive components, as well as by changes in the development of soil microorganisms. Microbiological degradation of dead plant tissues and secretions of some plant metabolites to the soil by roots cause changes in the microbial community and is followed by a selection of some species of microorganisms [33-34].

In most cases the authors have mentioned that soil microbial abundance and soil enzymatic activity were significantly greater in the crop rotation with full tillage (conventional tillage) compared with the monoculture with direct sowing. Differences in monoculture have strongly influenced soil enzyme activity, but without a major effect on microbial communities. In our study, there was no negative impact observed on biological activity in soil under maize cultivated in long-term monoculture. Enzyme activity is connected not only with plant species, but it also depends on the amount of plant remains from the depth of the root system. It can therefore be stated that maize is a very good plant to be grown in monoculture due to the large amount of root exudates in the soil.

Several environmental factors - including soil moisture, oxygen availability, oxidation reduction potential, $\mathrm{pH}$, organic matter content, depth of the soil profile, temperature, season, and soil fertilization can significantly affect enzymatic activities in the soil environment [7, 35-36].

Soil phosphatase can also be a good indicator of biological activity in soil $[7,34]$. Determining alkaline and acid phosphatase in the soil samples gives us large amount of information about biological characteristics of the soil. Phosphatase activity in soil reflects the activity of enzymes associated with soil colloids and humic substances and frees phosphatases in the soil solution and phosphatases associated with live and dead cells, plants, and microorganisms [34-35].

The relationship between enzymatic activity and soil properties, especially organic carbon content, the presence of clay minerals, and soil sorption complex have been observed by many researchers $[4,7,34]$.

According to Nannipieni et al. [7], alkaline phosphatase, catalase, and amidase are the best indicators of biological activity and population size of soil microorganisms. The activity of these enzymes showed the highest correlation with microbial biomass and microbial community in soils. Also, soil phosphatase activity is positively correlated with the number of soil microorganisms and organic carbon content, total nitrogen, and $\mathrm{pH}$. The highest acid phosphatase activity was observed in soil under growth in maize in monoculture (direct sowing) (Fig 3a). There were no statistically significant differences in acid phosphatase activity in 2007-12 (Fig. 3b), and also the phases of plant growth (Fig. 3c). The highest alkaline phosphatase activity was observed in 2009. There were no statistically 
a)

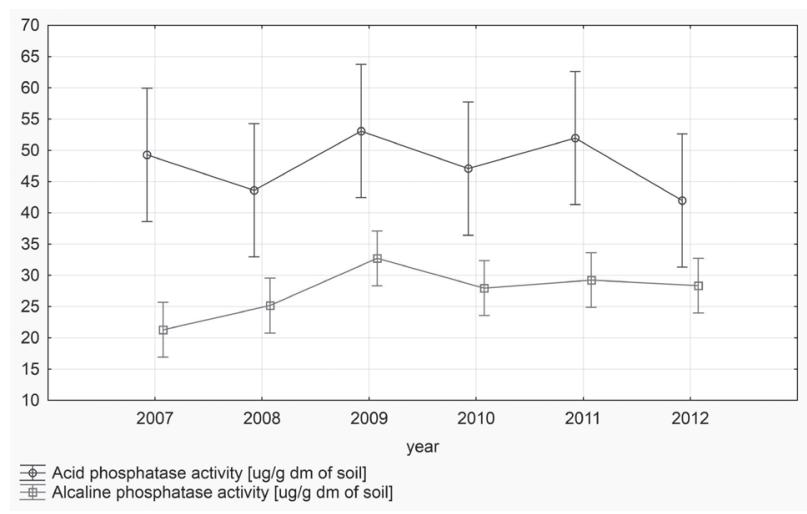

b)

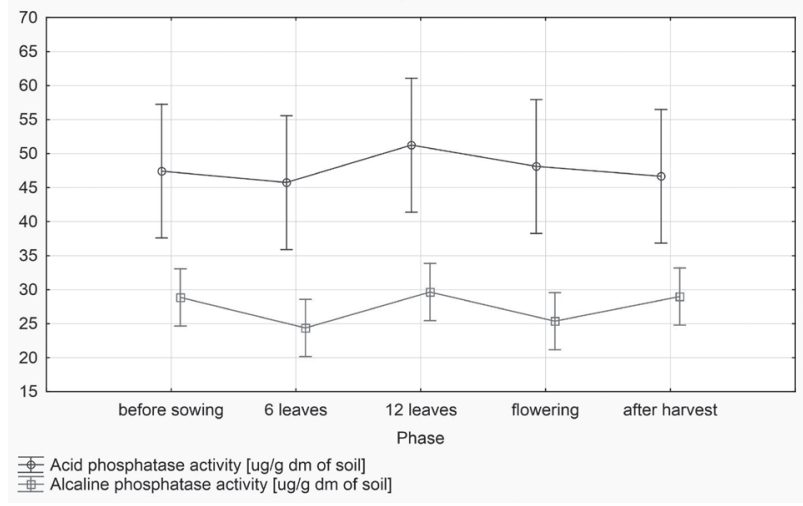

c)

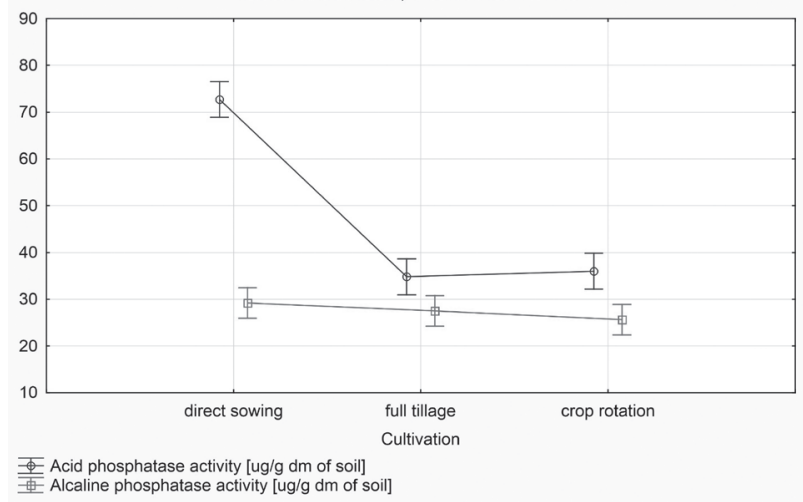

Fig. 3. Acid and alkaline activities in soil under maize a) in different years, b) in different phase of plants, and c) in different cultivation systems.

Note: Effective hypothesis decomposition Vertical bars denote 0,95 confidence intervals, a) year; LS Means Wilks lambda = 81420, $\mathrm{F}(10,166)=1,7968, \mathrm{p}=, 06467, \mathrm{~b})$ Phase; LS Means Wilks lambda $=93689, \mathrm{~F}(8,168)=69579, \mathrm{p}=, 69492, \mathrm{c})$ Cultivation; LS Means Wilks lambda $=25745, \mathrm{~F}(4,172)=$ $41,747, \mathrm{p}=0,0000$.

significant differences in alkaline phosphatase activity in 2007-12 (Fig. 3b).

Cultivation of plants in monoculture can lead to adverse changes in the soil environment related to the reduction of soil microbial diversity, as well as limiting the impact on crop yield [5, 25-26]. Long-term crop plants in monoculture induce and accelerate soil degradation processes that can lead to a reduction in the number of micro-organisms of the soil environment and the decline of organic matter [12, 31]. The cultivation of maize in monoculture in a no-tillage system in the conditions of our country is a good alternative, but requires further systematic research on system factors: climate-soilplant. Maize is one of the plants whose cultivation is very labour- and energy-intensive, hence agricultural practice is looking for cheaper and simpler solutions in the agricultural arena. Cultivation of maize in a no-tillage system is the most simplistic and is very attractive because it facilitates the organization of the field.

\section{Conclusions}

1. The highest biological activities of the soil were observed where direct sowing in monoculture was implemented.

2. The statistically significant increases in soil enzymatic activity and total number of bacteria and actinomycetes in soil were observed in soil where maize was cropped continuously (monoculture with zero tillage).

\section{Acknowledgements}

The research was conducted within the statutory activity of IUNG-PIB (2.08) and the frames of Task 1.4. Evaluation and formation of biodiversity of soil and microbial activity of soil with regard to habitat conditions and management system. Multi - Annual Programme IUNG - PIB 2016-2020.

\section{References}

1. KOTWICA K., JASKULSKA I., GAŁĘZEWSKI L., JASKULSKI D., LAMPARSKI R. The effect of tillage and management of post-harvest residues and biostymulant application on the yield of winter wheat in increasing monoculture. Acta Scientarum Polonorum, Agricultura, 13 (4), 65, 2014.

2. KSIĘŻOPOLSKA A., JONIEC J. Activity of microorganisms participating in organic matter transformation in haplic luvisol soil. The Society of Ecological Chemistry and Engineering, 21 (3), 499, 2014.

3. ADAMIAK E., ADAMIAK J. Changes of the chosen chemical properties of soil as a result of long-term cereal cultivation in crop rotation and monoculture. Acta Scientarum Polonorum Agricultura, 14 (1), 3, 2015.

4. BOWLES T.M., ACOSTA-MARTÍNEZ V., CALDERÓN F., JACKSON L.E. Soil enzyme activities, microbial communities, and carbon and nitrogen availability in organic agroecosystems across an intensively-managed agricultural landscape. Soil Biology and Biochemistry, 68, 252, 2014. 
5. JÄRVAN M., EDESI L., ADAMSON A., VÕSA T. Soil microbial communities and dehydrogenase activity depending on farming systems. Plant Soil and Environment, 60 (10), 459, 2014.

6. KARACA A., CETIN S.C., TURGAY O.C., KIZILKAYA R. Soil enzymes as indication of soil quality. In: Shukla G., Varma A. (eds.): Soil Enzymology. Springer-Verlag, Berlin, Heidelberg, 119, 2011.

7. NANNIPIERI P., ASCHER J., CECCHERINI M.T., LANDI L., PIETRAMELLARA G., RENELLA G. Microbial diversity and soil functions. European Journal of Soil Science, 54, 655, 2003.

8. TRIPATHI S., CHAKRABORTY A., CHAKRABARTI K., BANDYOPADHYAY B. Enzyme Activities and Microbial Biomass in Coastal Soils of India. Soil Biology \& Biochemistry, 39, 2840, 2007.

9. WOLIŃSKA A., STEPNIEWSKA Z., SZYMAŃSKA E. Dehydrogenase activity of soil microorganisms and the total DNA level in soil of different use. Journal of Agricultural Science and Technology B3, 613, 2013.

10. WŁODARCZYK T. Some Aspects of Dehydrogenase Activity in Soils. International Agrophysics, 22, 371, 2000.

11. YUAN B., YUE D. Soil Microbial and Enzymatic Activities Across a Chronosequence of Chinese Pine Plantation Development On The Loess Plateau of China. Pedosphere, 22, 1,2012

12. XIANG S., DOYLE A., HOLDEN P, SCHIMEL J. Drying and Rewetting Effects $\mathrm{On} \mathrm{C}$ and $\mathrm{N}$ mineralization and Microbial Activity In Surface and Subsurface California Grassland Soils. Soil Biology \& Biochemistry, 40, 2281, 2008.

13. SWEDRZYŃSKA D., MAŁECKA I., BLECHARCZYK A., SWĘDRZYŃSKI A., STARZYK J. Effects of varius long-term tillage system on same chemical and biological properties in soil. Polish Journal of Environmental Studies, 22 (6), 1835, 2013.

14. STANIAK M., KSIĘŻAK J., BOJARSZCZUK J. Weed infestation of maize cultivated in organic farming. Journal of Research and Applications in Agricultural Engineering, 56 (4), 123, 2011.

15. KSIĘŻAK J. Assessment of maize yields as affected by seedbed preparation method. Polish Journal of Agronomy, $2,33,2010$

16. SUBHANI A., CHANGYONG H., ZHENGMIAO Y., MIN L., EL-GHAMRY A. Impact of Soil Environment and Agronomic Practices On Microbial/Dehydrogenase Enzyme Activity In Soil. A Review. Pakistan Journal of Biological Sciences, 4, 333, 2001.

17. GAŁĄZKAA., KRÓL M., PERZYŃSKI A. Bioremediation of Crude Oil Derivatives In Soils Naturally And Artificially Polluted With The Use Of Maize As The Test Plant. Part I. PAHs Degradation. Acta Scientarum Polonorum, Agricultura, 9 (3), 13, 2010.

18. GAŁAZZKA A., KRÓL M., PERZYŃSKI A. The Efficiency of Rhizosphere Bioremediation with Azospirillum sp. and Pseudomonas stutzeri in Soils Freshly Contaminated with PAHs and Diesel Fuel. Polish Journal of Environmental Studies, 21 (2), 343, 2012.

19. MACHUL M., KSIĘŻAK J. Evaluation of yielding of maize depending on pre-sowing soil cultivation and method of nitrogen doses in conditions of monoculture and crop rotation. Fragmenta Agronomica, 95 (3), 292, 2007.

20. Polish Standard. PN-ISO 10381-6 Quality of soil- Collected samples- Principles of collcted and kept of soil samples to the microbiological research in laboratory conditions, 1998.
21. MARTIN J.P. Use of acid, rose bengal and streptomycin in the plate method for estimating soil fungi. Soil Science, 69, 215, 2003.

22. HATTORI R., HATTORI T. Sensitivity to salts and organic coumpounds of soil bacteria isolated on diluted media. The Journal of General and Applied Microbiology, 26, 1, 1980.

23. Polish Standard. PN-EN ISO 23753-1. Determination of dehydrogenase activity in soil using 2,3,5 triphenyltetrazolium chloride (TTC), 2011.

24. SHANNON D., SEN A.M., JOHNSON D.B. A comparative study of the microbiology of soils managed under organic and conventional regimes. Soil Use and Management, 18, 274, 2002.

25. CHU H., LIN X., FUJII T., MORIMOTO S., YAGI K., HU J., ZHANG J. Soil Microbial Biomass, Dehydrogenase Activity, Bacterial Community Structure In Response To Long-Term Fertilizer Management. Soil Biology \& Biochemistry, 39, 2971, 2007.

26. BLECHARCZYK A., MAŁECKA I., SKRZYPCZAK G. Effect of reduced tillage on yield, weed infestation of maize and soil properties. Acta Scientarum Polonorum, Agricultura 3 (1), 157, 2004.

27. KOPER J., PIOTROWSKA A., SIWIK-ZIOMEK A. Dehydrogenase and Inwertase Activities in a Rusty Soil in The Neighborhood of The Włocławek Nitrogen Plant "Anwill". Proceedings of ECOpole, 2, 197, 2008.

28. WANG S., WU Q.-S., HE X.-H. Egzogenous easily extractable glomalin-related soil protein promotes soil aggregation, relevant soil enzyme activities and plant growth in trifoliate orange. Plant Soil and Environment, 61 (2), 66, 2015.

29. WOLIŃSKA A., BENNICELLI R. Dehydrogenase Activity Response to Soil Reoxidation Process Described as Varied Condition of Water Potential, Air Porosity and Oxygen Availability. Polish Journal of Environmental Studies, 19, 651, 2010.

30. WOLNA-MARUWKA A. Dependence between enzymatic activity and the type of soil fertilization for maize cultivation in a monoculture. Polish Journal of Soil Science, XLI/I: $61,2008$.

31. WOLNA-MARUWKA A., NIEWIADOMSKA A., KLAMA J. Biological Activity of grey-brown podzolic soil organically fertilized for maize cultivation in monoculture. Polish Journal of Environmental Science, 5, 931, 2009.

32. NATYWA M., SELWET M. Respiratory and Dehydrogenase Activities in the Soils Under Maize Growth In The Conditions of Irrigated and Nonirrigated Fields. Agricultura, 10, 93, 2011.

33. SCHERER H.W., METKER D.J., WELP G. Effect of long-term organic amendments on chemical and microbial properties of a luvisol. Plant, Soil and Environment, 57, 513, 2011.

34. PARHAM J.A., DENG S.P., RAUN W.R., JOHNSON G.V. Long-term cattle manure application in soil. I. Effect on soil phosphorus levels, microbial biomass $\mathrm{C}$, and dehydrogenase and phosphatase activities. Biology and Fertility of Soils, 35, 328, 2002.

35. GAŁAZZKA A., GAŁĄZKA R. Phytoremediation of polycyclic aromatic hydrocarbons in soils artificially polluted using plant-associated-endophytic bacteria and Dactylis glomerata as the bioremediation plant. Polish Journal of Microbiology, 64 (3), 239, 2015.

36. ŁYSZCZ M., GAŁAZZKA A. Wybrane metody molekularne wykorzystywane w ocenie bioróżnorodności mikroorganizmów glebowych. Postępy Mikrobiologii 55 (3), 309, 2016. 